\title{
AMS RADIOCARBON DATING OF ANCIENT BONE USING ULTRAFILTRATION
}

\author{
T F G Higham ${ }^{1,2} \bullet$ R M Jacobi $^{3} \bullet$ C Bronk Ramsey ${ }^{1}$
}

ABSTRACT. The Oxford Radiocarbon Accelerator Unit (ORAU) has used an ultrafiltration protocol to further purify gelatin from archaeological bone since 2000. In this paper, the methodology is described, and it is shown that, in many instances, ultrafiltration successfully removes low molecular weight contaminants that less rigorous methods may not. These contaminants can sometimes be of a different radiocarbon age and, unless removed, may produce erroneous determinations, particularly when one is dating bones greater than 2 to 3 half-lives of ${ }^{14} \mathrm{C}$ and the contaminants are of modern age. Results of the redating of bone of Late Middle and Early Upper Paleolithic age from the British Isles and Europe suggest that we may need to look again at the traditional chronology for these periods.

\section{INTRODUCTION}

Despite its obvious appeal to archaeologists, most radiocarbon facilities date bone only rarely. The principal reason may be the often poor preservation of collagen in many contexts. Equally, however, there has been a traditional skepticism concerning the reliability of bone ${ }^{14} \mathrm{C}$ determinations among archaeologists (Burky et al. 1998), despite the obvious attraction of bone as a dating substrate that is usually related to the archaeological event rather well. Preservation of bone collagen is influenced principally by the environment within which the bone is deposited, and, specifically, by the interrelated influences of $\mathrm{pH}$, microbial activity, temperature, and water. However, these diagenetic influences can be extremely variable between, and within, sites (von Endt and Ortner 1984; Hedges and Millard 1995; Holmes et al. 2005). In general, there is a broad gradient in the preservation state of bones from those deposited in warmer, more humid environs to those recovered from archaeological contexts in colder, more temperate climes. Over many years, it has become apparent that the characterization of the quality of the extracted "collagen" is crucial to validate the accuracy of the obtained ${ }^{14} \mathrm{C}$ determinations. Several methods of achieving this have been described (e.g. DeNiro and Weiner 1988a; Ambrose 1990; van Klinken 1999), but few ${ }^{14} \mathrm{C}$ laboratories regularly apply the range of analytical measurements necessary to provide minimum assurance for submitters of bone samples (e.g. $\mathrm{C}$ to $\mathrm{N}$ ratios) even when the samples are of crucial importance to studies of late human evolution (e.g. Wild et al. 2005).

Bone "collagen" (we follow DeNiro and Weiner 1988; van Klinken 1999; and Hedges and van Klinken 1992 in using this term) is uniformly targeted for ${ }^{14} \mathrm{C}$ dating because it is the preeminent protein, and indigenous bone carbonate (hydroxyapatite) is so far inseparable from diagenetic carbonate. Individual collagen molecules contain 3 polypeptides that each comprise about 1000 amino acids per chain ("alpha chains"). These are arranged in fibrils, twisted into a right-handed coil weighing between 95 and $102 \mathrm{kD}(1 \mathrm{kD}=1000 \mathrm{amu}$ [atomic mass units] where $1 \mathrm{amu}=1 / 12$ mass of $1{ }^{12} \mathrm{C}$ atom). The most commonly applied pretreatment protocol is the so-called "Longin collagen method" in which "collagen" (the insoluble residue remaining after decalcification of the bone) is first isolated by decalcification, then denatured in weakly acidic water (gelatinization), untwisting the triple-helical collagen molecule and thereby reducing the influence of insoluble residues (Longin 1971). In many cases, this method produces gelatin that enables reliable ${ }^{14} \mathrm{C}$ ages to be determined, but it is difficult to validate with confidence the exclusive removal of exogenous carbon to

\footnotetext{
${ }^{1}$ Oxford Radiocarbon Accelerator Unit, RLAHA, Dyson Perrins Building, University of Oxford, Oxford OX1 3QY, United Kingdom.

${ }^{2}$ Corresponding author. Email: thomas.higham@ rlaha.ox.ac.uk.

${ }^{3}$ Department of Prehistory and Europe, Franks House, The British Museum, London N1 5QJ, United Kingdom; also Department of Palaeontology, Natural History Museum, London SW7 5BD, United Kingdom.
} 
low levels (about $<0.1-0.2 \%$ modern carbon) particularly in bone where collagen preservation is poor (about 1-2 wt\% collagen). Some workers have shown, however, that this method is not sufficiently rigorous to remove all contaminants in problem bones, for example in bone where humic compounds are present or have cross-linked with collagen (Brown et al. 1988; van Klinken and Hedges 1995; Bronk Ramsey et al. 2004a) or where bone has very low levels of remaining collagen (e.g. $<1 \mathrm{wt} \%$ ). Novel means of further purifying bone have been developed, including the use of ninhydrin derivatization (Nelson 1991; Tisnerat-Laborde et al. 2003), ion-exchange techniques (Hedges et al. 1989b), the isolation of single amino acids (usually hydroxyproline) (Stafford et al. 1987, 1991; van Klinken and Mook 1990), collagenase digestion (DeNiro and Weiner 1988b; van Klinken et al. 1994), isolation of tripeptides (van Klinken et al. 1994), and ultrafiltration (Brown et al. 1988).

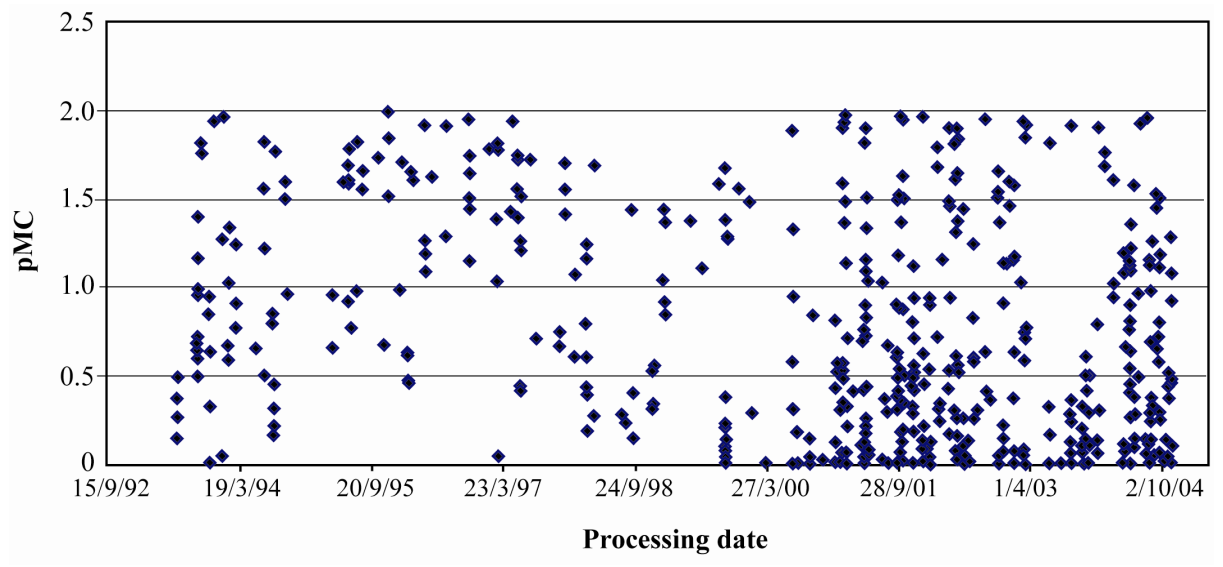

Figure 1 ORAU bone pMC values $<2.0$ plotted against processing date. There is a change in the distribution at $8 / 2000$ (see text for details). One additional reason for the increasing number of determinations $<0.4 \mathrm{pMC}$ is that many of the dated bones are from northern temperate and sub-arctic locations, such as Alaska and Siberia, where preservation of bone collagen is favored generally by lower temperatures and permafrost conditions, and extractable yields are therefore higher.

Since 2000, we have applied an ultrafiltration protocol based on the method originally outlined by Brown et al. (1988), to separate high molecular weight (MW) components of the gelatinized "collagen" ( $>30 \mathrm{kD})$ (including undegraded alpha chains) from low MW fractions $(<30 \mathrm{kD})$ (which will include broken-down/degraded collagen fragments, salts, and soil-derived amino acids, among other potential contaminants). The complete ORAU bone pretreatment method is outlined in Bronk Ramsey et al. (2004a; see also 2000). In our experience, the use of ultrafilters improves the quality of the extracted "collagen," judging by improved C:N ratios and other analytical parameters. Ultrafiltration also eliminates salt components that can make handling of the gelatin problematic.

However, some problems with ultrafiltration have been encountered. In earlier work, our group showed that humectants (glycerol) used to coat the regenerated-cellulose membrane of the ultrafilters used at ORAU remained partially unremoved after manufacturer-recommended cleaning protocols were applied (Bronk Ramsey et al. 2004a). This resulted in age offsets of $\sim 100-300 \mathrm{yr}$ for low gelatin yield bones $\left(<50 \mathrm{mg}\right.$ gelatin), which are particularly significant for bones of $<2{ }^{14} \mathrm{C}$ halflives, since the glycerol was $>35 \mathrm{kyr}$ BP in age. It is therefore crucial that effective cleaning protocols be undertaken prior to the use of ultrafiltration in ${ }^{14} \mathrm{C}$ pretreatment. Our new protocol and quality assurance data are outlined by F Brock, C Bronk Ramsey, and TFG Higham (unpublished data). 


\section{DATING ANCIENT BONE USING ULTRAFILTRATION}

Since ultrafiltration was adopted at ORAU, a larger number of accelerator mass spectrometry (AMS) determinations $<2$ pMC (about $>31,000$ BP) have been obtained (Figure 1) than was previously the case. Pretreatment chemistry is of key importance, as described below, but other developments are also considered relevant. Reductions in measurement background and increasing levels of measurement precision have been achieved during the same period (Bronk Ramsey et al. 2004b). Since 2000, the range and breadth of standards specific to the sample type we most regularly date, which is bone, have been widened. The additional standards routinely dated include:

- Two bison bones from Alaska assessed to be $>60 \mathrm{kyr}$ in age on the basis of multiple AMS repeat dates;

- Pig (Sus scrofa) rib bones from the Mary Rose (the flagship of Henry VIII, which sank in $\mathrm{AD}$ 1545).

In addition, we have also introduced a further standard:

- Mammoth bone $40 \mathrm{kyr}$ BP, a partial pelvis recovered from the Quartz Creek site, Alaska. Currently, this is being used for the VIRI intercomparison (sample E).

The $>60-$ kyr BP standards ( 2 bison bones from Alaska) are used as blanks and regularly analyzed to quantify a background correction to account for chemical pretreatment processing of bone (Bronk Ramsey et al. 2004a). Low and high mass amounts of bone are regularly pretreated and dated. Low mass is defined in this instance as the lowest starting weight from which we can obtain enough "collagen" for a 1.7-mg graphite sample (i.e. 4-5 mg ultrafiltered gelatin). When these bison bones are corrected for graphitization and machine background, the results show that for bone $>10 \mathrm{mg}$ ultrafiltered gelatin (our minimum extractable yield for routine bone samples), the value for pMC averages $-0.020 \pm 0.16$, which suggests that our bone background subtraction is accurate.

Since the limit for reporting finite ${ }^{14} \mathrm{C}$ ages is reached at twice the total standard error $(\sigma)$ for an individual ${ }^{14} \mathrm{C}$ measurement (Stuiver and Polach 1977), $\mathrm{T}_{\max }$ (the maximum determinable age) is strongly influenced by measurement precision. Increasing routine measurement precision, coupled with modifications to both the breadth and regularity of sample-specific standards described above, has resulted in a reduction in the value for $\mathrm{T}_{\max }$. Initial testing of the new Oxford HVEE AMS showed that the system is capable of measuring the ${ }^{14} \mathrm{C} /{ }^{13} \mathrm{C}$ and ${ }^{14} \mathrm{C} /{ }^{12} \mathrm{C}$ ratios at a precision of up to $0.2 \%$ (Bronk Ramsey et al. 2004b). The scatter of results for known-age materials, such as tree rings, at this level of precision is not higher than the reported standard error. This shows that the quoted errors are not being overestimated. One in every 20 samples dated at ORAU is duplicated from the beginning of pretreatment chemistry, which provides a reasonable assessment of routine reproducibility and, ultimately, a test of whether or not quoted precisions are justified. Bronk Ramsey et al. (2004b) showed that the reproducibility of repeat measurements on standards matched closely the uncertainties ( \pm values) quoted. To achieve a determination of $>50 \mathrm{kyr} \mathrm{BP}$, the measurement precision must be better than, or equal to, $\pm 0.1 \mathrm{pMC}$ (Figure 2). Ultimately, of course, the limiting factor in terms of dating samples of bone to $\sim 50 \mathrm{kyr} B P$ is sample-specific rather than instrument or measurement related and requires the elimination of small amounts of more modern contamination. Evidence collected since ultrafilters were included in the pretreatment of bone at Oxford suggests that this technique is a significant improvement in the AMS dating of this material. 


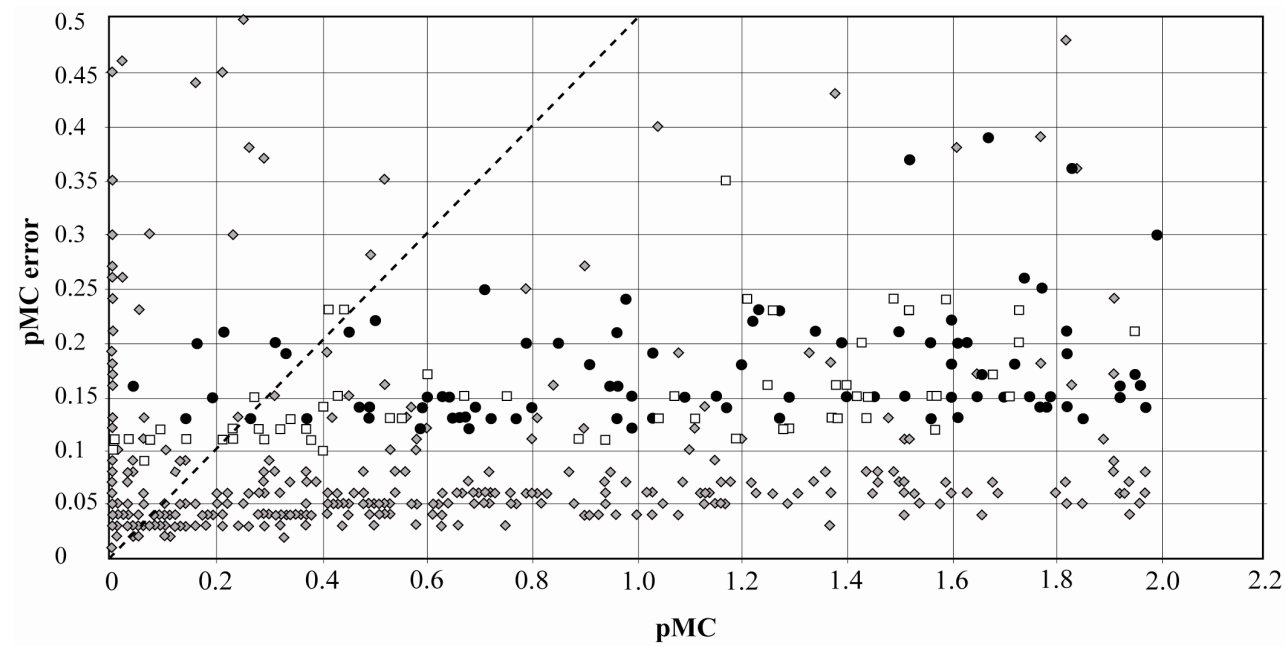

Figure $2 \mathrm{pMC}$ plotted against pMC error. Each point is a ${ }^{14} \mathrm{C}$ measurement in $\mathrm{pMC}$ dated at ORAU over the last $15 \mathrm{yr}<2 \mathrm{pMC}$. The dashed line represents "pMC error $\times 2$," which defines $\mathrm{T}_{\max } . \mathrm{pMC}$ values to the left of this line are "greater than" ages. To obtain finite AMS age determinations $>50 \mathrm{kyr}$ BP, a precision of $\pm 0.1 \mathrm{pMC}$ is required. The diamonds are ultrafiltered gelatin determinations. This figure shows an increase in the number of these compared with other measurements of ion exchanged (black circles) and gelatin determinations (open squares). Our conclusion is that this is due principally to 1) the increased levels of measurement precision produced since the installation of the new HVEE accelerator (see text) and 2) the introduction of ultrafiltration in the routine pretreatment of bone, improving the removal of contaminants in very old bone material.

\section{METHOD}

Ultrafiltration pretreatments have been tested upon a number of important European Middle and Upper Paleolithic bone samples, many of which have been dated before in Oxford or other laboratories, using other pretreatment chemistries. Initial results reported recently (Bronk Ramsey et al. 2004a; Jacobi et al., forthcoming) showed that ultrafiltration appeared to remove contaminating carbon more effectively than other methods and produced dates that were often older than those prepared using less rigorous methods. In many instances, determinations suspected of being aberrant because of their unexpectedly young age with respect to stratigraphy or cultural attribution were redated using ultrafiltration. These initial Oxford dates were pretreated using 1 of 3 methods:

1. Purified amino acids (ORAU laboratory code AC). The bone was decalcified, and the insoluble residue was hydrolyzed and treated with activated charcoal before the separation of the amino acids from inorganic solutes with cation-exchange columns and Dowex 50W-X8 resin (Gillespie et al. 1984; Gillespie and Hedges 1983); this method was used prior to 1989.

2. Ion-exchanged gelatin (code AI). The bone was decalcified, usually with a continuous-flow apparatus (see Law and Hedges 1989; Hedges et al. 1989b). A sodium hydroxide wash was applied to partially remove humic contaminants. The insoluble collagen was gelatinized and purified using an ion-exchange column with BioRad AGMP-50 resin. This method was used until 2000. It was abandoned because of concerns regarding the possibility of column resin bleed and the difficulty in excluding this as a potential contaminant (see also Burky et al. 1998).

3. Gelatin (code AG). After decalcification, $\mathrm{pH} 3$ water was added to a $20-\mathrm{mL}$ sample tube and the "collagen" heated at $75^{\circ} \mathrm{C}$ for about $20 \mathrm{hr}$. The tube was centrifuged to collect supernatants and filtered using a $9-\mu \mathrm{m}$ Eezi ${ }^{\mathrm{TM}}$ filter. The gelatin was lyophilized prior to dating. This method has 
been used since 1997 and is still occasionally applied, mainly for modern samples or samples of very small starting weight.

The ultrafiltration pretreatment method is coded "AF" in our laboratory. These codes are used in the tables throughout this paper. Asterisks (e.g. AF*) denote the addition of a solvent pre-wash step (usually using methanol and chloroform). AMS dates of bone of known age using a solvent extraction have shown, when compared with the same bones dated without one, no significant differences in age. We use a solvent wash on bone suspected of being conserved or glued.

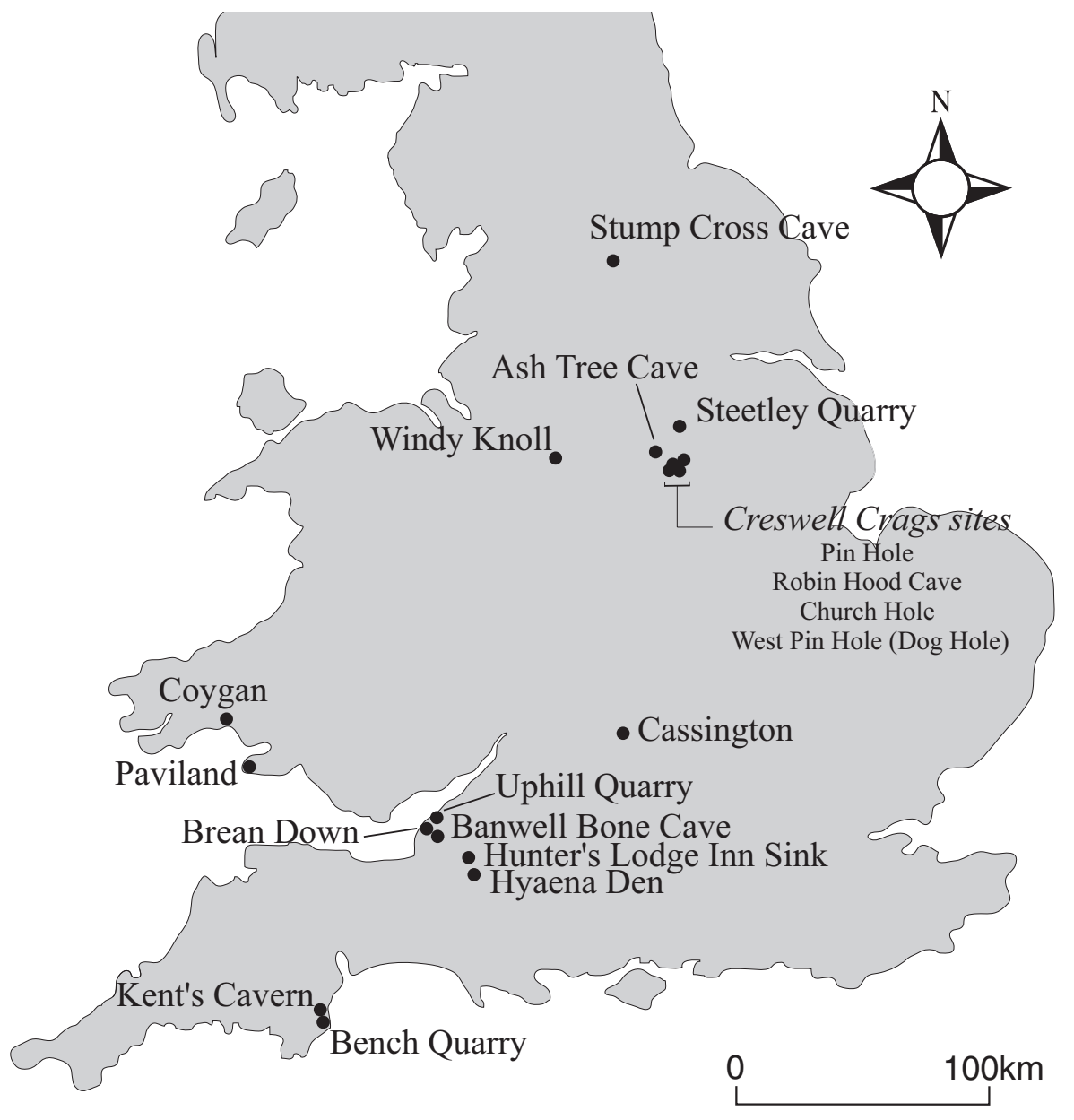

Figure 3 Location of British sites mentioned in this paper

\section{BONE FROM MARINE OXYGEN ISOTOPE STAGE (MOIS) 5 OR 4}

Currant and Jacobi $(1997,2001)$ have identified a cool climate, low species-diversity fauna dominated by bison (Bison priscus) and reindeer (Rangifer tarandus) as occurring at a large number of Late Pleistocene sites in England and Wales. Dating evidence is sparse, but at Stump Cross Cavern in North Yorkshire a fauna of this type is dated by U-series determinations to the latter part of MOIS 5 (Baker et al. 1996), and a similar age has been proposed for a fauna from Cassington, near Oxford (Maddy et al. 1998) (Figure 3). It has been suggested (Currant and Jacobi 2001) that this 
fauna may have persisted into MOIS 4, but this is uncertain. In either case, we would expect ${ }^{14} \mathrm{C}$ determinations on bones from these faunas to be beyond the ${ }^{14} \mathrm{C}$ limit. In Table 1, previously dated samples of bones from faunas of this type are listed. They include finite results.

Samples of bone from Ash Tree Cave and Windy Knoll (Derbyshire), Steetley Quarry (Nottinghamshire), Hunter's Lodge Inn Sink (Somerset), and Banwell Bone Cave and Brean Down (North Somerset) have been dated (Figure 3; Tables 1 and 2). These data show that where samples of bone from this fauna have been redated using ultrafiltration, the results are almost always "greater than" ages and substantially older than previously thought. This both confirms the suspected great age of this fauna and suggests that earlier finite AMS analyses of this fauna were inaccurate. The application of ultrafiltration techniques improves the removal of trace contaminants and consequently reduces the measured ${ }^{14} \mathrm{C}$ ages.

Table 1 AMS ${ }^{14} \mathrm{C}$ determinations of bones from Banwell Bone Cave mammal assemblage-zone sites previously AMS dated in Oxford. AF denotes ultrafiltered gelatin determinations, AG denotes a filtered gelatin determination, and AI denotes ion exchanged gelatin, as described in the text. Stable isotope ratios are expressed in relative to vPDB and nitrogen to AIR. Mass spectrometric precision is $\pm 0.2 \%$ o for carbon and $\pm 0.3 \%$ o for nitrogen. $\mathrm{Wt} \%$ coll. is the amount of collagen extracted as a percentage of the starting weight. Pretreat. yield is the weight in milligrams of the freeze-dried, ultrafiltered gelatin or ion-exchanged gelatin product, depending on the pretreatment method. $\mathrm{CN}$ is the atomic ratio of carbon to nitrogen. $\% \mathrm{C}$ is the percentage of carbon in the combusted ultrafiltered gelatin. Each ultrafiltered determination is a direct re-date of the previous sample given above it. In the tables that follow, asterisks in the pretreatment code column denote a solvent extraction prior to bone pretreatment in order to remove potential conservation materials from the bones prior to dating, as described earlier in the text.

\begin{tabular}{|c|c|c|c|c|c|c|c|c|c|}
\hline Element/species & $\begin{array}{l}\text { OxA- } \\
\text { number }\end{array}$ & ${ }^{14} \mathrm{C}$ age $\mathrm{BP}$ & Method & $\mathrm{CN}$ & $\delta^{13} \mathrm{C}$ & $\delta^{15} \mathrm{~N}$ & $\begin{array}{l}\mathrm{Wt} \% \\
\text { coll. }\end{array}$ & $\begin{array}{l}\text { Pretreat. } \\
\text { yield }(\mathrm{mg})\end{array}$ & $\% \mathrm{C}$ \\
\hline \multicolumn{10}{|c|}{ Windy Knoll, Derbyshire } \\
\hline \multirow{2}{*}{$\begin{array}{l}\text { Bison priscus, } \\
\text { radius }\end{array}$} & OxA-4579 & $37,300 \pm 1100$ & AI & & -20.1 & & 1.4 & 6.8 & 61.8 \\
\hline & OxA-15001 & $>51,700$ & AF & 3.2 & -20.8 & 4.6 & 10.1 & 94.5 & 42.6 \\
\hline \multicolumn{10}{|c|}{ Steetley Quarry, Nottinghamshire } \\
\hline \multirow{2}{*}{$\begin{array}{l}\text { Bison priscus, } \\
\text { metacarpal }\end{array}$} & OxA-2846 & $>44,700$ & $\mathrm{AI}$ & & -22.2 & & 8.3 & 25 & 44.1 \\
\hline & OxA-15000 & $>53,200$ & $\mathrm{AF}$ & 3.2 & -20.6 & 9.4 & 2.7 & 14 & 43.3 \\
\hline \multicolumn{10}{|c|}{ Brean Down, North Somerset } \\
\hline \multirow{2}{*}{$\begin{array}{l}\text { Canis lupus, } \\
\text { humerus }\end{array}$} & OxA-4582 & $41,200 \pm 1600$ & AI & & -19.8 & & 1.5 & 5.0 & 48.0 \\
\hline & OxA-15002 & $>52,700$ & $\mathrm{AF}$ & 3.2 & -19.5 & 10.5 & 1.7 & 12.1 & 41.8 \\
\hline \multicolumn{10}{|c|}{ Ash Tree Cave, Derbyshire (clay) } \\
\hline \multirow{2}{*}{$\begin{array}{l}\text { Bison priscus, } \\
\text { cervical vertebra }\end{array}$} & OxA-7736 & $>41,500$ & AG & 3.3 & -20.9 & 5.6 & 6.2 & 75.6 & 31.2 \\
\hline & OxA-15003 & $>57,700$ & $\mathrm{AF}$ & 3.2 & -20.6 & 6.6 & 2.6 & 25.6 & 42.1 \\
\hline
\end{tabular}

\section{THE BRITISH LATE MIDDLE PALEOLITHIC}

\section{Pin Hole}

The first archaeological site examined in this paper is the cave of Pin Hole, in Creswell Crags gorge, Derbyshire (Figure 3). The samples are all from the lower of 2 cave-earths, investigated by Leslie Armstrong between 1924 and 1936. The artifacts from this sediment are all Middle Paleolithic, and we would therefore expect ages of $>\sim 40 \mathrm{kyr}$ BP. Previous uranium-series and electron spin resonance (ESR) dates from the site have supported this conclusion (Jacobi et al. 1998). A series of ionexchanged gelatin ${ }^{14} \mathrm{C}$ dates (Hedges et al. 1989a) produced a minimum age for the fauna from the 
Table 2 AMS ${ }^{14} \mathrm{C}$ determinations of bones from Banwell Bone Cave mammal assemblage-zone faunas excavated from the sites of Ash Tree Cave, Banwell Bone Cave, and Hunter's Lodge Inn Sink. All analyses are ultrafiltered determinations. See the Table 1 caption for details of the other analytical information. $\dagger$ indicates duplicate determinations.

\begin{tabular}{lllllllll}
\hline & $\begin{array}{c}\text { OxA- } \\
\text { number }\end{array}$ & ${ }^{14} \mathrm{C}$ age BP & $\mathrm{CN}$ & $\delta^{13} \mathrm{C}$ & $\delta^{15} \mathrm{~N}$ & $\begin{array}{l}\text { Wt\% } \\
\text { coll. }\end{array}$ & $\begin{array}{l}\text { Pretreat. } \\
\text { yield (mg) }\end{array}$ & $\% \mathrm{C}$ \\
\hline Element/species & & & & & & & \\
\hline Ash Tree Cave, Derbyshire (clay) & & & & & & & \\
Bison priscus, metatarsal & 13800 & $>54,100$ & 3.3 & -20.4 & 8.8 & 3.7 & 30.0 & 46.8 \\
Bone fragment & 13801 & $>56,500$ & 3.3 & -20.4 & 9.9 & 6.4 & 47.7 & 47.1 \\
Bone fragment & 13802 & $52,800 \pm 3100$ & 3.3 & -20.2 & 10.0 & 2.4 & 17.0 & 43.3 \\
Banwell Bone Cave, North Somerset & & & & & & & \\
Bison priscus, calcaneum & 14136 & $>59,500$ & 3.2 & -20.3 & 10.8 & 14.8 & 59.0 & 41.2 \\
Bison priscus, calcaneum & $14137 \dagger$ & $52,700 \pm 1900$ & 3.2 & -20.6 & 11.1 & 6.0 & 35.0 & 41.7 \\
& $14138 \dagger$ & $>53,900$ & 3.1 & -20.7 & 10.6 & 3.5 & 14.6 & 41.1 \\
Hunter's Lodge Inn Sink, Somerset & & & & & & & \\
Bison priscus, scapula & 13566 & $>54,800$ & 3.2 & -20.6 & 8.8 & 3.6 & 17.9 & 43.2 \\
\hline
\end{tabular}

same levels as the Middle Paleolithic artifacts of 40 kyr BP (Table 3) (Jacobi et al. 1998). How much older the fauna and the archaeology might be remained largely unresolved, although the Useries dates suggested that the sediments in which these occurred were more recent than $\sim 64 \mathrm{kyr} B \mathrm{P}$ (Jacobi et al. 1998). The resolution of this problem could be addressed using a new dating program involving improved pretreatment chemistry. This new series is shown in Table 3 and illustrated in Figure 4. The results reported here expand on those in Jacobi et al. (forthcoming).

Ultrafiltration has resulted in older, and sometimes substantially older, results, some of which are $>50 \mathrm{kyr}$ BP. It is noticeable that what in several cases were infinite ages have now become finite. This suggests that ultrafilters are more effectively removing the kind of contaminants that previous methods were not. Dates obtained previously in Oxford using ion-exchanged gelatin (Hedges et al. 1989a) were underestimates of the true age.

In the absence of cut-marked and human-modified bone from this site, there is no possibility of further refining the age of its occupation by Neanderthal humans. The same problem applies to the adjacent site of Robin Hood Cave, where a broadly similar chronology has been obtained for its Middle Paleolithic archaeology (Jacobi et al., forthcoming).

\section{Coygan Cave}

Coygan Cave, now quarried away, overlooked Carmarthen Bay in South Wales (Figure 3). It was investigated several times during the 19th and 20th centuries, the most recent excavations in 196364 being directed by John Clegg and Charles McBurney. It is from this excavation that dating samples have been obtained. The site is of importance for yielding evidence of use by Middle Paleolithic humans and, more extensively, for denning by spotted hyaenas (Crocuta crocuta: Aldhouse-Green et al. 1995).

Dating of flowstones by Henry Schwarcz suggested that the cave had been closed for much of the Late Pleistocene, only reopening some time after $\sim 64 \mathrm{kyr}$ BP (Aldhouse-Green et al. 1995). Apart from a single small piece of carbonized large-mammal bone, there is no human-modified bone from the cave, so human presence remains undated. There are, however, 5 dates on bone and tooth that directly date hyaena activity in the cave and, by association, date when the cave could have been open for human occupation (Table 4). Each sample included ultrafiltration in its pretreatment, and it 
Table 3 AMS ${ }^{14} \mathrm{C}$ determinations from Pin Hole, Creswell Crags. Context data are derived from markings made by Armstrong on the individual specimens. They record distance into the cave from a datum at the entrance and depth below the deposit surface. See the Table 1 caption for details of the analytical data. AC code describes purified amino acids; see text for details. OxA-14197 yielded a conventional ${ }^{14} \mathrm{C}$ measurement of 55,900 $\pm 4000 \mathrm{BP}$, while OxA-11979 gave a result of 58,800 \pm 3700 BP. Since October 2005, ORAU has treated the effective limit for bone AMS determinations at $55 \mathrm{kyr}$ BP. In this table, these determinations are therefore recalculated as shown. Dates obtained from context $64 / 11^{\prime} 0^{\prime \prime}$ are from the same woolly rhinoceros radius, and include 2 determinations made from the same analyzed sample of bone (OxA-11979 and OxA-X-2116-6), the second of which is the $<30-\mathrm{kD}$ fraction of the bone hydrolyzate. This fraction is therefore discarded routinely at ORAU, but in this instance we retained and AMS dated it to evaluate the age of this fraction, which is composed of degraded collagen and probably a small amount of contamination. The other 2 determinations from this bone (OxA-14211 and -14212) were drilled from 2 different sampling loci on the radius. Taken together, all 3 of the AF determinations from this specimen yield acceptable reproducibility.

\begin{tabular}{|c|c|c|c|c|c|c|c|c|c|}
\hline $\begin{array}{l}\text { Sample find } \\
\text { coordinate }\end{array}$ & Species/Element & $\begin{array}{l}\text { Pretreat. } \\
\text { code }\end{array}$ & $\begin{array}{l}\text { OxA- } \\
\text { number }\end{array}$ & ${ }^{14} \mathrm{C}$ age $\mathrm{BP}$ & $\mathrm{CN}$ & $\delta^{13} \mathrm{C}$ & $\delta^{15} \mathrm{~N}$ & $\begin{array}{l}\mathrm{Wt} \% \\
\text { coll. }\end{array}$ & $\% \mathrm{C}$ \\
\hline \multirow[t]{2}{*}{$37 / 9^{\prime} 6^{\prime \prime}$} & \multirow{2}{*}{$\begin{array}{l}\text { Mammuthus primigenius, } \\
\text { right navicular }\end{array}$} & AI & 4431 & $42,700 \pm 2100$ & & -22.6 & & 9.7 & 47 \\
\hline & & AF & 12737 & $48,400 \pm 1100$ & 3.1 & -21.7 & 7.9 & 6.9 & 45 \\
\hline $42 / 11^{\prime} 6^{\prime \prime}$ & $\begin{array}{l}\text { Coelodonta antiquitatis, } \\
\text { calcaneum }\end{array}$ & $\mathrm{AF}$ & 14197 & $>47,900$ & 3.2 & -20.0 & 4.4 & 3.8 & 44 \\
\hline $44 / 8^{\prime} 6^{\prime \prime}$ & $\begin{array}{l}\text { Coelodonta antiquitatis, } \\
\text { right } \mathrm{P}_{4}\end{array}$ & AF & 13592 & $43,350 \pm 650$ & 3.1 & -19.8 & 1.8 & 7.2 & 44 \\
\hline \multirow[t]{3}{*}{$48 / 8^{\prime} 6^{\prime \prime}$} & \multirow{3}{*}{$\begin{array}{l}\text { Coelodonta antiquitatis, } \\
\text { right tibia }\end{array}$} & AI & 4428 & $42,700 \pm 2200$ & & -20.3 & & 7.6 & 47 \\
\hline & & $\mathrm{AF}$ & 13564 & $>43,000$ & 3.2 & -19.7 & n.d. & 0.7 & 43 \\
\hline & & $\mathrm{AF}$ & 13880 & $52,500 \pm 2800$ & 3.3 & -19.8 & 3.5 & 3.5 & 43 \\
\hline \multirow[t]{2}{*}{$50 / 7^{\prime} 0^{\prime \prime}$} & \multirow{2}{*}{$\begin{array}{l}\text { Coelodonta antiquitatis, } \\
\text { right } \mathrm{P}_{4}\end{array}$} & AI & 4429 & $>42,300$ & & -19.2 & & 8.4 & 51 \\
\hline & & $\mathrm{AF}$ & 13881 & $45,000 \pm 750$ & 3.2 & -19.2 & 4.7 & 5.0 & 45 \\
\hline \multirow[t]{3}{*}{$50 / 8^{\prime} 0^{\prime \prime}$} & \multirow[t]{3}{*}{ Equus ferus, incisor } & AI & 4430 & $44,900 \pm 2800$ & & -20.2 & & 7.3 & 51 \\
\hline & & $\mathrm{AG}$ & 13590 & $44,300 \pm 2100$ & 3.1 & -20.9 & 5.9 & 3.5 & 41 \\
\hline & & $\mathrm{AF}$ & 13889 & $47,000 \pm 1200$ & 3.2 & -20.8 & 3.9 & 4.6 & 42 \\
\hline \multirow[t]{2}{*}{$50 / 10^{\prime} 0^{\prime \prime}$} & \multirow[t]{2}{*}{ Coelodonta antiquitatis, ulna } & $\mathrm{AC}$ & 1813 & $>41,400$ & & -21.0 & & 10.8 & 23 \\
\hline & & $\mathrm{AF}$ & 12808 & $54,000 \pm 2900$ & 3.2 & -20.1 & 2.4 & 4.1 & 42 \\
\hline \multirow[t]{2}{*}{$53 / 7^{\prime} 6^{\prime \prime}$} & \multirow[t]{2}{*}{ Bovini, left radius/ulna } & AI & 4427 & $>44,200$ & & -18.7 & & 5.5 & 55 \\
\hline & & $\mathrm{AF}$ & 13591 & $48,000 \pm 1000$ & 3.1 & -19.8 & 6.6 & 11.0 & 43 \\
\hline $62 / 9^{\prime} 0^{\prime \prime}$ & $\begin{array}{l}\text { Equus ferus, } \\
\text { metapodial fragment }\end{array}$ & $\mathrm{AF}$ & 11978 & $53,000 \pm 1900$ & 3.2 & -20.6 & 5.6 & 6.4 & 41 \\
\hline $64 / 7^{\prime} 0^{\prime \prime}$ & Rangifer tarandus, antler & $\mathrm{AF}$ & 11796 & $44,200 \pm 800$ & 3.3 & -17.5 & 1.6 & 4.5 & 41 \\
\hline $64 / 9^{\prime} 0^{\prime \prime}$ & Equus ferus, right navicular & $\mathrm{AF}$ & 11977 & $49,600 \pm 1000$ & 3.3 & -20.6 & 4.0 & 11.6 & 42 \\
\hline \multirow[t]{4}{*}{$64 / 11^{\prime} 0^{\prime \prime}$} & \multirow{4}{*}{$\begin{array}{l}\text { Coelodonta antiquitatis, } \\
\text { right radius }\end{array}$} & $\mathrm{AF}$ & 11979 & $>51,400$ & 3.3 & -19.7 & 3.4 & 7.1 & 41 \\
\hline & & $\begin{array}{l}\mathrm{AF} \\
(<30 \mathrm{kD})\end{array}$ & X-2116-6 & $49,000 \pm 800$ & 3.1 & -20.2 & 2.7 & 2.7 & 42 \\
\hline & & AF & 14211 & $53,400 \pm 1700$ & 3.4 & -19.6 & 3.1 & 8.4 & 45 \\
\hline & & $\mathrm{AF}$ & 14212 & $50,200 \pm 1400$ & 3.1 & -19.4 & 4.0 & 4.2 & 50 \\
\hline $65 / 8^{\prime} 0^{\prime \prime}$ & Rangifer tarandus, antler & $\mathrm{AF}$ & 11797 & $40,650 \pm 500$ & 3.4 & -18.5 & 0.8 & 4.8 & 45 \\
\hline $65 / 9^{\prime} 0^{\prime \prime}$ & Bovini, partial right tibia & $\mathrm{AF}$ & 11976 & $40,720 \pm 390$ & 3.3 & -20.4 & 2.5 & 11.7 & 54 \\
\hline
\end{tabular}

is noticeable that all are considerably older than a determination obtained in 1990 for a hyaenagnawed radius of woolly rhinoceros of $24,620 \pm 320 \mathrm{BP}$ (OxA-2509: Hedges et al. 1994). This determination was $<1 \mathrm{wt} \%$ collagen and, therefore, potentially problematic (see sections below). OxA-14401, the oldest date, appears out of sequence, but there are bones of rabbit (Oryctolagus cuniculus) from this context, which indicate that bioturbation within the site is a distinct possibility. 
Pin Hole sample co-ordinates

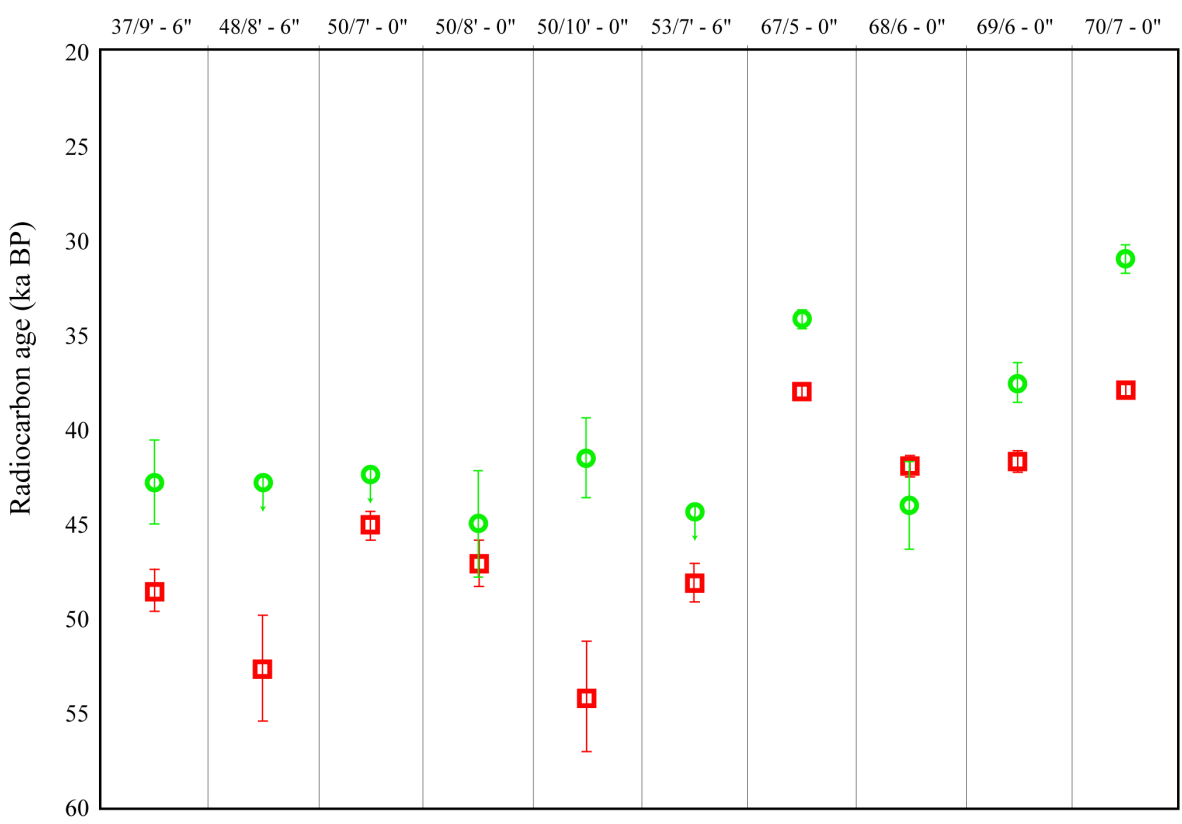

Figure 4 Comparison between initial AMS dates from Pin Hole, pretreated using ion-exchanged gelatin techniques (squares) and a new series based on ultrafiltration (circles). The results are presented in order based on distance into the cave from the datum point at the entrance.

Table $4{ }^{14} \mathrm{C}$ determinations from Coygan Cave, South Wales. As indicated previously, all asterisks denote a solvent extraction prior to collagen pretreatment. The failed samples were mistakenly not solvent-extracted and therefore failed. These will be resampled in the near future. See the Table 1 caption for other analytical details.

\begin{tabular}{|c|c|c|c|c|c|c|c|c|c|}
\hline $\begin{array}{l}\text { Sample } \\
\text { reference }\end{array}$ & Species/element & $\begin{array}{l}\text { Pretreat. } \\
\text { code }\end{array}$ & $\begin{array}{l}\text { OxA- } \\
\text { number }\end{array}$ & ${ }^{14} \mathrm{C}$ age $\mathrm{BP}$ & $\mathrm{CN}$ & $\delta^{13} \mathrm{C}$ & $\delta^{15} \mathrm{~N}$ & $\begin{array}{l}\mathrm{Wt} \% \\
\text { coll. }\end{array}$ & $\% \mathrm{C}$ \\
\hline Spit 11108 & C. crocuta $\mathrm{C}$ & $\mathrm{AF}^{*}$ & 14400 & $32,140 \pm 250$ & 3.2 & -18.6 & 11.2 & 4.8 & 49.2 \\
\hline Spit 11109 & C. crocuta $\mathrm{C}$ & $\mathrm{AF}^{*}$ & 14401 & $43,000 \pm 2100$ & 3.2 & -18.3 & 10.7 & 1.0 & 49.2 \\
\hline Spit 41037 & C. crocuta $\mathrm{P}_{3}$ & $\mathrm{AF}$ & Fail & & & & & & \\
\hline Spit 51049 & C. crocuta $\mathrm{M}_{1}$ & $\mathrm{AF}^{*}$ & 14473 & $32,400 \pm 550$ & 3.3 & -19.1 & 9.6 & 1.6 & 35.3 \\
\hline Spit 51059 & $\begin{array}{l}\text { C. crocuta } \\
\text { left dentary }\end{array}$ & $\mathrm{AF}$ & Fail & & & & & & \\
\hline Spit 61070 & C. crocuta $\mathrm{I}_{3}$ & $\mathrm{AF}^{*}$ & 14402 & $36,000 \pm 500$ & 3.2 & -18.3 & 11.6 & 3.4 & 50.4 \\
\hline Spit 71078 & C. crocuta $\mathrm{P}_{3}$ & $\mathrm{AF}^{*}$ & 14403 & $39,700 \pm 1700$ & 3.3 & -17.3 & 10.8 & 1.3 & 45.4 \\
\hline
\end{tabular}

\section{THE BRITISH MIDDLE TO UPPER PALEOLITHIC}

\section{Kent's Cavern}

The site of Kent's Cavern (Torquay, Devon) is one of the most important Paleolithic sites in Britain. The oldest human fossil from SW England, a fragmentary human maxilla, comes from here and was excavated in March 1927 (KC4: Oakley et al. 1971). Its context was in cave-earth at a depth of 10'6" in an excavation against the north wall of the Vestibule, the entrance chamber to the cave. This was directly dated at Oxford in 1988 and gave an age of 30,900 \pm 900 BP (OxA-1621: Hedges et al. 
1989a:209). The specimen is so fragmentary that it is uncertain whether the human represented possessed an anatomically modern morphology or was a Neanderthal. This problem may be resolved by an analysis of the DNA signature of the specimen. Questions also arise regarding the reliability of the AMS date because it is now apparent that the maxilla had been treated with a thin, water-soluble glue. Further AMS dates using ultrafiltration have therefore been obtained to constrain the age of the maxilla more reliably. The bones and teeth dated come from directly above and beneath its find context (Table 5).

Table 5 AMS ${ }^{14} \mathrm{C}$ determinations from Kent's Cavern. See the Table 1 caption for details of the analytical information and the text for information regarding the pretreatment codes. Results are presented in increasing depth below the datum, which is the granular stalagmite. Note that the $\delta^{13} \mathrm{C}$ value for OxA-1621 is not a measured value but an estimate. The correct value ought to be closer to $-19 \pm 2$. We have not recorrected the original AMS date to this value since there is no actual stable isotope measurement, and the correction will not result in a substantially different result. The deepest Upper Paleolithic artifact from this trench is at $15^{\prime}$. In closely adjacent trenches excavated between 1934 and 1938, and using the same datum, Middle Paleolithic artifacts were recovered from depths between $13^{\prime} 9^{\prime \prime}$ and $17^{\prime} 6^{\prime \prime}$. There is, therefore, the possibility of an overlap between Early Upper Paleolithic and Late Middle Paleolithic materials in the lowest part of the Upper Paleolithic range. This is taken to be the explanation for the older ${ }^{14} \mathrm{C}$ determinations in this table between $13^{\prime} 3^{\prime \prime}$ and $15^{\prime}$. OxA-14761 was duplicated as part of ORAU's internal QA program at $47,700 \pm 3700 \mathrm{BP}$.

\begin{tabular}{|c|c|c|c|c|c|c|c|c|c|}
\hline Depth & Element/species & $\begin{array}{l}\text { Pretre. } \\
\text { code }\end{array}$ & $\begin{array}{l}\text { OxA- } \\
\text { number }\end{array}$ & ${ }^{14} \mathrm{C}$ age $\mathrm{BP}$ & $\mathrm{CN}$ & $\delta^{13} \mathrm{C}$ & $\delta^{15} \mathrm{~N}$ & $\begin{array}{l}\mathrm{Wt} \% \\
\text { coll. }\end{array}$ & $\% \mathrm{C}$ \\
\hline \multirow[t]{2}{*}{$8^{\prime} 3^{\prime \prime}$} & \multirow{2}{*}{$\begin{array}{l}\text { Coelodonta antiquitatis, } \\
\text { right metacarpal } 3\end{array}$} & $\mathrm{AI}$ & 3450 & & & -19.7 & & 1.0 & 42.5 \\
\hline & & $\mathrm{AF}^{*}$ & 13921 & 36, & 3.4 & -19.6 & 6.4 & 5.5 & 36.6 \\
\hline \multirow[t]{3}{*}{$8^{\prime} 3^{\prime \prime}$} & \multirow{3}{*}{$\begin{array}{l}\text { Coelodonta antiquitatis, } \\
\text { right metacarpal } 4\end{array}$} & $\mathrm{~A}$ & 3449 & 34,5 & & -19.3 & & 3.9 & 41.0 \\
\hline & & $\mathrm{AF}^{*}$ & 14210 & $36,370=$ & 3.3 & -20.1 & 7.1 & 6.0 & 44.5 \\
\hline & & $\mathrm{AF}^{*}$ & 14701 & 35,65 & 3.3 & -19.4 & 7.4 & 5.8 & 43.6 \\
\hline $9^{\prime} 0^{\prime \prime}$ & ctos, left d & $\mathrm{AF}^{*}$ & 14059 & $35,600 \pm 700$ & 3.2 & -19.0 & 11.5 & 0.95 & 41.7 \\
\hline \multirow[t]{2}{*}{$9^{\prime} 6^{\prime \prime}$} & \multirow{2}{*}{$\begin{array}{l}\text { Coelodonta antiquitatis, } \\
\text { cranial fragment }\end{array}$} & $\mathrm{AI}$ & 6108 & 30 , & & -20.0 & & 2.3 & 42.4 \\
\hline & & $\mathrm{AF}$ & 13965 & 37,200 & 3.2 & -20.1 & 6.2 & 2.6 & 40.2 \\
\hline $10^{\prime} 6 "$ & Homo sp., right maxilla & $\mathrm{AC}$ & 1621 & $30,900 \pm 900$ & & -26.0 & & 1.7 & \\
\hline $12-13^{\prime}$ & $\begin{array}{l}\text { Coelodonta antiquitatis, } \\
\text { distal right tibia }\end{array}$ & $\mathrm{AF}^{*}$ & 14715 & $35,150 \pm 330$ & 3.3 & -19.4 & 6.5 & 3.44 & 41.8 \\
\hline $13^{\prime} 3^{\prime \prime}$ & Panthera leo, left $\underline{\mathrm{C}}$ & $\mathrm{AF}$ & 14285 & $43,600 \pm 3600$ & 3.2 & -17.4 & 13.3 & 0.44 & 54.7 \\
\hline $14^{\prime} 0^{\prime \prime}$ & $\begin{array}{l}\text { Coelodonta antiquitatis, } \\
\text { left unciform }\end{array}$ & $\mathrm{AF}^{*}$ & 14761 & $45,000 \pm 2200$ & 3.4 & -19.9 & 6.4 & 1.7 & 42.0 \\
\hline \multirow[t]{2}{*}{$15^{\prime} 0^{\prime \prime}$} & \multirow{2}{*}{$\begin{array}{l}\text { Rangifer tarandus, } \\
\text { left dentary }\end{array}$} & $\mathrm{AG}^{*}$ & 13589 & $37,900 \pm 1000$ & 3.1 & -18.9 & 7.1 & 1.5 & 41.4 \\
\hline & & $\mathrm{AF}$ & 13888 & $40,000 \pm 700$ & 3.3 & -18.5 & 5.1 & 2.8 & 41.9 \\
\hline $19-20^{\prime}$ & $\begin{array}{l}\text { Rangifer tarandus, } \\
\text { proximal radius }\end{array}$ & $\mathrm{AF}^{*}$ & 14714 & $49,600 \pm 2200$ & 3.3 & -18.6 & 5.4 & 3.1 & 40.3 \\
\hline
\end{tabular}

Once again, ultrafiltered gelatin ages are older than those previously obtained. This is particularly the case with the cranial fragment of woolly rhinoceros found only a short way above the maxilla (compare OxA-6108 and -13965). The pair of woolly rhinoceros metacarpals (3 and 4) articulate, and the agreement between the ages for these 2 bones indicates acceptable reproducibility. The lion canine produced a very low yield ( $0.44 \mathrm{wt} \%$ collagen $)$, so the standard error was larger than ideal. 
The new results suggest that the previously obtained age for the maxilla was a severe underestimate and that its most likely age is, instead, between 35-37 kyr BP. This makes even more tantalizing the problem of its attribution. The artifacts found with the maxilla are very few but are clearly Upper Paleolithic; however, they cannot be culturally diagnosed. The deepest sample, the radius of reindeer (OxA-14714), was found deeper than any archaeological finds in this part of the cave, which includes Middle Paleolithic as well as Upper Paleolithic artifacts.

\section{Uphill Quarry and the Hyaena Den}

Recent researchers tend to correlate the spread of anatomically modern humans with an Aurignacian technology (Bocquet-Appel and Demars 2000; Kozlowski and Otte 2000; Davies 2001; Conard and Bolus 2003; Mellars 2004a,b). This suggestion makes the direct dating of the Aurignacian of considerable interest. For Britain, 2 artifacts assume importance in this context: a lozangic bone/antler point from Uphill, near Weston-super-Mare (North Somerset), and a bone/antler point from the Hyaena Den at Wookey Hole (Somerset), some $25 \mathrm{~km}$ to the west (Figure 3).

The Uphill point was dated in 1999 using filtered gelatin and produced an age of 28 kyr BP (Jacobi and Pettitt 2000) (Table 6). This would have implied an Aurignacian presence at, or very close to, the time when ${ }^{14} \mathrm{C}$ determinations indicate that a Gravettian technology may have been in existence in Belgium (Vrielynk 1999; Haesaerts and Damblon 2004). Davies and Gollop (2003) suggested that, if reliable, this would imply Aurignacian humans living in an area of extensive contemporary snow cover, which was unlikely. This specimen was therefore redated using ultrafiltration in 2004.

Table $6{ }^{14} \mathrm{C}$ determinations of the Aurignacian lozenge-shaped point from Uphill (Bristol City Museum BRSMG Ce 16476 Up). OxA-8408 was reported previously by Jacobi and Pettitt (2000). See Table 1 caption for analytical details.

\begin{tabular}{llllllll}
\hline $\begin{array}{l}\text { OxA- } \\
\text { number }\end{array}$ & Method & ${ }^{14} \mathrm{C}$ age BP & $\mathrm{CN}$ & $\delta^{13} \mathrm{C}$ & $\delta^{15} \mathrm{~N}$ & $\begin{array}{l}\text { Wt\% } \\
\text { coll. }\end{array}$ & $\% \mathrm{C}$ \\
\hline 8408 & $\mathrm{AG}$ & $28,080 \pm 360$ & 3.3 & -17.3 & 1.0 & 9.1 & 35.0 \\
13716 & AF & $31,730 \pm 250$ & 3.2 & -17.5 & 1.2 & 9.4 & 43.7 \\
\hline
\end{tabular}

Once again, the new age is substantially older than the previous gelatin age (Table 6). The point is therefore contemporary with the Aurignacian II as defined for SW France on the basis of lithic industries (Djindjian 1992). This correlates well with the sparse typological clues that can be deduced from Aurignacian lithic artifacts found at other sites in the British Isles, e.g. Paviland on the Gower coast of South Wales.

Table $7{ }^{14} \mathrm{C}$ determination of a Paleolithic bone or antler point from the Hyaena Den. See Table 1 caption for analytical details.

\begin{tabular}{lllllllll}
\hline $\begin{array}{l}\text { OxA- } \\
\text { number }\end{array}$ & Method & ${ }^{14} \mathrm{C}$ age BP & $\mathrm{CN}$ & $\delta^{13} \mathrm{C}$ & $\delta^{15} \mathrm{~N}$ & Wt\% coll. & $\begin{array}{l}\text { yretreat. } \\
\text { yield }(\mathrm{mg})\end{array}$ & $\% \mathrm{C}$ \\
\hline 3451 & AI & $24,600 \pm 300$ & n.d. & -20.1 & n.d. & 0.96 & 2.4 & 45.8 \\
13803 & AF $^{*}$ & $31,550 \pm 340$ & 3.4 & -19.2 & 2.3 & 2.0 & 11.7 & 41.8 \\
\hline
\end{tabular}

The point from the Hyaena Den was found between 1890-95 by Edward Brooks in a part of the cave well away from the Middle and Early Upper Paleolithic (Jerzmanowician) artifacts for which the site is better known. It is similar to points from Aurignacian contexts, such as La Ferrassie (Hahn 1988: Figure 3.4) and the Abri Blanchard (Leroy-Prost 1979: Figure 86.8). Bone from this point was 
first dated in 1991 using the ion-exchanged gelatin method (Table 7). Archaeologically, the result implied a Late Gravettian age with human presence in Britain at a time of lowering temperatures. The ultrafiltered age obtained is again significantly older, confirming its likely cultural attribution to the Aurignacian. The ages for both of these points are intriguingly similar, perhaps documenting the activities of the same human group. The sites are linked by the River Axe.

\section{THE FRENCH EARLY UPPER PALEOLITHIC}

In the light of the results described above, the current work has been extended to the important French Paleolithic sequences derived from sites in the Dordogne, including La Ferrassie and the Abri Pataud (Mellars and Bricker 1986). These sites have been selected for reinvestigation because their chronologies are so often cited in discussions of the Early Upper Paleolithic in western Europe and the spread of anatomically modern humans. Comparisons are often made with their lithic industries when assessing the age of other sites. For both sites, the new dates once more suggest that the published chronologies are underestimates of the true situation.

The freshly dated material consists of bone obtained from amongst material previously submitted by Prof Paul Mellars (Cambridge University) and archived at ORAU. The first sample is from the Abri Pataud, which was excavated by Movius $(1975,1977)$. The locality is one of the most extensively ${ }^{14} \mathrm{C}$-dated Early Upper Paleolithic site in Europe, with 34 dates from the Groningen laboratory and another 16 from Oxford, all obtained prior to the 1990s.

There are 14 cultural levels at this rock shelter. The newly dated bone was selected because of the clear cut-marks visible on its surface and is from level 13 (Table 8), the lowest but one of the Aurignacian layers. The date obtained is the oldest for the Aurignacian at this site and suggests that previously dated burnt bone samples from around and beneath the level of this sample are likely to be underestimates of the true age by $\sim 2000{ }^{14} \mathrm{C}$ yr. This is of considerable interest for confirming how early anatomically modern humans may have been present in this area. More work is planned.

The dating of the archaeological levels at the nearby site of La Ferrassie has been more complicated. A large series of dates from the Gif-sur-Yvette laboratory produced dates that, in many instances, were younger than those initially produced in Oxford. OxA-402 to -404, for instance, are older than Gif dates obtained from the same levels (Gowlett et al. 1986:214; Mellars and Bricker 1986: Figure 2). However, our reanalysis shows that these Oxford dates are also likely to be underestimates.

Samples obtained by Mellars from the excavations of Delporte (1984), and archived at ORAU, were reexamined. Two samples of large herbivore bone were selected for dating, one of which was clearly cut-marked (OxA-15218). The other had been previously dated (OxA-403). The ultrafiltered repeat date was again significantly older (OxA-15217; Table 8). The date for OxA-15218 comes from one of the levels designated by Delporte (1984) as Aurignacian II. The sample from level D2h is from a level with early Gravettian Font-Robert points and is the oldest determination for an industry of this type. Again, further work is proposed to expand on these results.

\section{THE RUSSIAN EARLY UPPER PALEOLITHIC}

It is important to emphasize that by no means have all of the Paleolithic bone determinations we reanalyzed produced older ${ }^{14} \mathrm{C}$ ages. The majority of low yielding and/or contaminated bones tend to follow this pattern, but where bone is reasonably well preserved, gelatinization is likely to be an effective pretreatment. An important redated human bone sample from Russia illustrates this point well. 
Table 8 New ${ }^{14} \mathrm{C}$ determinations (AF* codes) reported from the Abri Pataud and La Ferrassie. $\delta^{13} \mathrm{C}$ values for all $\mathrm{AC}$ determinations are estimated. OxA-15217 is a repeat of OxA-403.

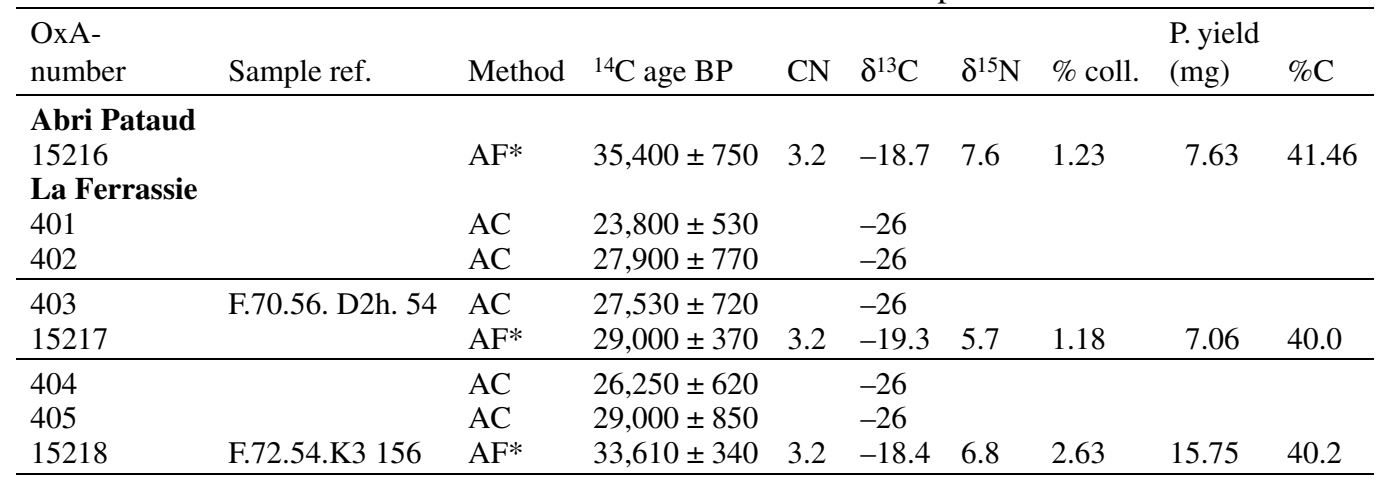

The human remains come from the 3rd cultural layer of Kostenki 1, which is attributed to the Aurignacian. Kostenki 1 is in Russia's Voronezh region and is the most easterly site of this industry yet identified. The bone was excavated by Dr Andrei Sinitsyn (Sinitsyn 2003). The gelatin date obtained in 1997 from a human femur was reanalyzed using ultrafiltration and both results are statistically indistinguishable from each other (Table 9). The standard error of the new determination, however, is substantially reduced. The second Aurignacian assemblage within the immediate area (Kostenki 14 [Markina gora]) has a charcoal determination of 32,420 +440/-420 (GrA-18053) (Sinitsyn, personal communication).

Table 9 Bone determinations from Kostenki 1, Russia.

\begin{tabular}{lllllllll}
\hline $\begin{array}{l}\text { OxA- } \\
\text { number }\end{array}$ & Method & ${ }^{14} \mathrm{C}$ age BP & $\mathrm{CN}$ & $\delta^{13} \mathrm{C}$ & $\delta^{15} \mathrm{~N}$ & $\begin{array}{l}\mathrm{Wt} \% \\
\text { coll. }\end{array}$ & $\begin{array}{l}\text { P. yield } \\
(\mathrm{mg})\end{array}$ & $\% \mathrm{C}$ \\
\hline 7073 & $\mathrm{AG}$ & $32,600 \pm 1100$ & 3.0 & -18.2 & 15.8 & 3.6 & 20.2 & 41.2 \\
15055 & $\mathrm{AF}$ & $32,070 \pm 190$ & 3.2 & -18.5 & 14.8 & 9.6 & 144.0 & 38.1 \\
\hline
\end{tabular}

This result demonstrates that not all Paleolithic bone dates obtained using an AG pretreatment are problematic. The major shifts in age identified above tend to be associated with those bones producing often very low collagen yields or those that were probably contaminated, or both. This is well illustrated in the next section.

\section{FAILED BONES}

A number of hyaena teeth that were initially dated using gelatin or ion-exchanged gelatin techniques have been reanalyzed using ultrafiltration and have failed because sufficient collagen could not be obtained. In these cases, it is suspected that the initial determinations are probably unreliable, since doubts are cast upon the preservation state of the bone collagen, which increases the possibility for contamination to be significant in its influence.

Samples falling into this category include:

- OxA-5798 (25,660 $\pm 380 \mathrm{BP})$ was an ion-exchanged gelatin date on a hyaena tooth from Ash Tree Cave (Derbyshire). We pretreated and ultrafiltered $370 \mathrm{mg}$ of dentine redrilled anew from this specimen but obtained $0 \mathrm{mg}$ yield. We suspected the original date to be erroneously young from its stratigraphic context. 
- OxA-5800 (24,000 $\pm 260 \mathrm{BP})$ was a date for a hyaena incisor from Church Hole (on the Nottinghamshire side of Creswell Crags gorge). This determination is among the youngest of any hyaena dated in the British Isles. The tooth was originally selected for dating because all of the other hyaena material from Church Hole was treated with glue. The original ion-exchanged gelatin date produced a yield of $2.0 \mathrm{mg}$ from $340 \mathrm{mg}$ of dentine. We attempted to redate this specimen, but the remaining material consists almost completely of tooth enamel that has been shown to be problematic for ${ }^{14} \mathrm{C}$ dating (Hedges et al. 1995). The sample was therefore failed.

- OxA-5801 (33,450 $\pm 700 \mathrm{BP})$ was a date for a hyaena tooth from Late Glacial sediments outside the west entrance to Robin Hood Cave (Derbyshire). The initial ion-exchanged date comprised an analyzed sample of $500 \mathrm{mg}$ of dentine from which $10.4 \mathrm{mg}$ of collagen was obtained. The determination appears to be suspicious since the reanalysis using ultrafiltration resulted in a 0.6-mg ultrafiltered gelatin yield from a 405-mg dentine starting weight. This reanalysis was therefore considered failed due to this low yield.

- OxA-6114 (22,980 $\pm 480 \mathrm{BP})$ was an incisor recovered in 1981 from a small excavation in the southwest corner of the Western Chamber of Robin Hood Cave. Middle Paleolithic artifacts were recovered at this time. Fresh dentine was drilled from the tooth $(143 \mathrm{mg})$ but produced a 0 -mg yield of collagen after being ultrafiltered.

- OxA-5803 (29,300 $\pm 420 \mathrm{BP})$ was a date of dentine from a hyaena tooth found in the spoil from West Pin Hole (Dog Hole), Creswell Crags (Derbyshire). Our reanalysis of this sample resulted in a $0-\mathrm{mg}$ collagen yield from $106 \mathrm{mg}$ of dentine.

These failures suggest strongly that the initial dates ought to be considered problematic, since the attempts to redate the samples show that there is little or no recoverable collagen of acceptable quality in the teeth. These ${ }^{14} \mathrm{C}$ results ought to be set aside from serious consideration in the archaeological literature. Convincing evidence in support of this conclusion comes from 2 hyaena teeth from this initial series that did produce very small amounts of extractable ultrafiltered collagen but yielded substantially different ages (Table 10).

Table $10{ }^{14} \mathrm{C}$ determinations of hyaena teeth from Church Hole and Robin Hood Cave, Creswell, Derbyshire. See Table 1 caption for analytical details.

\begin{tabular}{|c|c|c|c|c|c|c|c|c|}
\hline $\begin{array}{l}\text { OxA- } \\
\text { number }\end{array}$ & Method & ${ }^{14} \mathrm{C}$ age $\mathrm{BP}$ & $\mathrm{CN}$ & $\delta^{13} \mathrm{C}$ & $\delta^{15} \mathrm{~N}$ & $\begin{array}{l}\mathrm{Wt} \% \\
\text { coll. }\end{array}$ & $\begin{array}{l}\text { Pretreat. } \\
\text { yield }(\mathrm{mg})\end{array}$ & $\% \mathrm{C}$ \\
\hline \multicolumn{9}{|c|}{ Church Hole Cave (CHC20-24, CC3, tooth, Crocuta crocuta) } \\
\hline 5799 & AI & $26,840 \pm 420$ & & -20.6 & & 0.31 & 1.1 & 34.5 \\
\hline 14926 & $\mathrm{AF}$ & $>40,000$ & 3.2 & -18.8 & 11.3 & 1.62 & 2.4 & 42.5 \\
\hline \multicolumn{9}{|c|}{ Robin Hood Cave (RH121-132, 1969, OB,16,197, CC6, tooth, Crocuta crocuta) } \\
\hline 5802 & AI & $31,050 \pm 500$ & & -19.1 & & 1.79 & 5.0 & 36.0 \\
\hline 14944 & $\mathrm{AF}$ & $>49,800$ & 3.2 & -18.8 & 12.8 & 2.16 & 8.5 & 43.9 \\
\hline \multicolumn{9}{|c|}{ Robin Hood Cave (RH1238 1981 excavation A spit 26, tooth, Crocuta crocuta) } \\
\hline 6115 & AI & $22,880 \pm 240$ & & -20.8 & & 2.87 & 15.5 & 43.5 \\
\hline 12736 & $\mathrm{AF}$ & $>52,800$ & 3.1 & -18.1 & 9.2 & 3.47 & 12.5 & 43.5 \\
\hline
\end{tabular}

\section{CONCLUSIONS}

${ }^{14} \mathrm{C}$-dated bones that contain a proportion of undegraded collagen generally produce reliable and accurate determinations, which can be validated where appropriate analytical data are collected and adequate purification techniques are applied. ${ }^{14} \mathrm{C}$ dating of bone that is low in collagen is much more 
challenging and sometimes can result in erroneous determinations (for this reason, ORAU does not date bone below 1-wt $\%$ collagen or 10-mg collagen pretreatment yield, unless circumstances are exceptional). For these types of bones, it is crucial that both rigorous purification techniques are applied and adequate screening methods are routinely implemented. The AMS dating of bone from the Middle and Upper Paleolithic periods has considerably improved with additional pretreatment using ultrafiltration, judging by the results presented here. Some workers (e.g. Jöris et al. 2003) have noted that where charcoal and bone are dated from identical contexts in Paleolithic Europe, bone often produces younger ages by comparison. Our results show that, once again (see also Brown et al. 1988; Hedges and van Klinken 1992), ultrafiltration often increases the measured age compared with simple gelatinization and could, in part, contribute to the resolution of this problem. In addition, ultrafiltration effectively acts as a screening method by eliminating bone of dubious quality, that is, bone that has a low yield of recoverable collagen of sufficient quality. Ultrafiltration will not remove contaminants greater in molecular weight than the molecular weight cut-off of the filters, so higher mass contaminants, such as unbroken cross-linked humic complexes, will not be removed (see also van Klinken and Hedges 1995). However, the potential problems associated with these types of samples can be minimized by the routine collection of a suite of subsidiary analytical data (see Hedges and van Klinken 1992; van Klinken 1999), such as those given in the tables of this paper. The reliability of some previous Oxford ion-exchanged gelatin determinations is questioned. For some of these determinations, it is possible that the presence of resin from column bleed may be an equally important influence, particularly in those cases where pretreatment yields were very low.

Other factors are crucial in contributing to the general improvement in dating bone from this period. The background limit of ${ }^{14} \mathrm{C}$ dating bone has been demonstrably reduced over recent years in Oxford. Improved AMS instrumentation and measurement precision and the use of a battery of bone standards of infinite and finite age similarly contribute. The dates obtained on Paleolithic bone in general make much more archaeological sense when compared with those previously dated. A detailed reanalysis of ages from the European Middle to Upper Paleolithic record is clearly required, and it is to this end that we are now working.

\section{ACKNOWLEDGMENTS}

We thank the Leverhulme Trust-funded "Ancient Human Occupation of Britain" (AHOB) project and the NERC-AHRC Oxford Radiocarbon Accelerator Dating Service (ORADS) for providing funding for this work. We thank the staff (past and present) of the Oxford Radiocarbon Accelerator Unit, University of Oxford, for their careful analytical preparation and AMS work. Dr Alistair Pike (Bristol) and Tony Jarratt (Wells, Somerset) have allowed us to quote results from Ash Tree Cave, Banwell Bone Cave, and Hunter's Lodge Inn Sink, respectively. We thank Prof Paul Mellars (Cambridge) for permission to redate the French material and Dr Andrei Sinitsyn (St Petersburg) for permission to report the new Kostenki date. Silvia Bello (AHOB) produced the map for us. We acknowledge with gratitude the many museum curators who have collaborated with us in this project. We acknowledge useful discussions and comments from Dr Tom Brown (LLNL Center for Accelerator Mass Spectrometry, University of California, Livermore).

\section{REFERENCES}

Aldhouse-Green S, Scott K, Schwarcz H, Grün R, Housley R, Rae A, Bevins R, Redknap M. 1995. Coygan Cave, Laugharne, South Wales, a Mousterian site and hyaena den: a report on the University of Cambridge excavations. Proceedings of the Prehistoric Society 61:37-79.
Ambrose SH. 1990. Preparation and characterisation of bone and tooth collagen for isotopic analysis. Journal of Archaeological Science 17:431-51.

Baker A, Smart PL, Edwards RL. 1996. Mass spectrometric dating of flowstones from Stump Cross Caverns and Lancaster Hole, Yorkshire: palaeoclimate im- 
plications. Journal of Quaternary Science 11:107-14.

Bocquet-Appel J-P, Demars PY. 2000. Neanderthal contraction and modern human colonization of Europe. Antiquity 74(285):544-52.

Bronk Ramsey C, Pettitt PB, Hedges REM, Hodgins GWL, Owen DC. 2000. Radiocarbon dates from the Oxford AMS system: Archaeometry datelist 30. Archaeometry 42(2):459-79.

Bronk Ramsey C, Higham TFG, Bowles A, Hedges REM. 2004a. Improvements to the pretreatment of bone at Oxford. Radiocarbon 46(1):155-63.

Bronk Ramsey C, Higham TFG, Leach P. 2004b. Towards high-precision AMS: progress and limitations. Radiocarbon 46(1):17-24.

Brown TA, Nelson DE, Vogel JS, Southon JR. 1988. Improved collagen extraction by modified Longin method. Radiocarbon 30(2):171-7.

Burky RR, Kirner DL, Taylor RE, Hare PE, Southon JR. 1998. ${ }^{14} \mathrm{C}$ dating of bone using $\gamma$-carboxyglutamic acid and $\alpha$-carboxyglycine (aminomalonate). Radiocarbon 40(1):11-20.

Conard NJ, Bolus M. 2003. Radiocarbon dating the appearance of modern humans and timing of cultural innovations in Europe: new results and new challenges. Journal of Human Evolution 44(3):331-71.

Currant AP, Jacobi RM. 1997. Vertebrate faunas of the British Late Pleistocene and the chronology of human settlement. Quaternary Newsletter 82:1-8.

Currant AP, Jacobi RM. 2001. A formal mammalian biostratigraphy for the Late Pleistocene of Britain. Quaternary Science Reviews 20(16-17):1707-16.

Davies SWG. 2001. A very model of a modern human industry: new perspectives on the origins and spread of the Aurignacian in Europe. Proceedings of the Prehistoric Society 67:195-217.

Davies SWG, Gollop P. 2003. The human presence in Europe during the Last Glacial Period II: climate tolerance and climate preferences of Mid- and Late Glacial hominids. In: van Andel TH, Davies W, editors. Neanderthals and Modern Humans in the European Landscape During the Last Glaciation: Archaeological Results of the Stage 3 Project. Cambridge: McDonald Institute for Archaeological Research. p 131-46.

Delporte H. 1984. Le Grand Abri de la Ferrassie: Fouilles 1968-1973. Éditions du Laboratoire de Paléontologie Humaine et de Préhistoire. Études Quaternaires, Géologie, Paléontologie, Préhistoire, Memoire no. 7. In French.

DeNiro MJ, Weiner S. 1988a. Chemical, enzymatic and spectroscopic characterisation of "collagen" and other organic fractions from archaeological bones. Geochimica et Cosmochimica Acta 52:2197-206.

DeNiro MJ, Weiner S. 1988b. Use of collagenase to purify collagen from prehistoric bones for stable isotopic analysis. Geochimica et Cosmochimica Acta 52: 2425-31

Djindjian F. 1992. L'Aurignacien du Périgord. Une révi- sion. Préhistoire Européenne 3:29-54. In French.

Gillespie R, Hedges REM. 1983. Sample chemistry for the Oxford high energy mass spectrometer. Radiocarbon 25(2):771-4.

Gillespie R, Hedges REM, Wand JO. 1984. Radiocarbon dating of bone by accelerator mass spectrometry. Journal of Archaeological Science 11:165-70.

Gowlett JAJ, Hedges REM, Law IA, Perry C. 1986. Radiocarbon dates from the AMS system: Archaeometry datelist 4. Archaeometry 28(2):206-21.

Haesaerts P, Damblon F. 2004. Les dates radiocarbone de Maisières-Canal. In: Miller R, Haesaerts P, Otte M, editors. Études et Recherches Archéologiques de l'Université de Liège (ERAUL) 110. Latelier de taille aurignacien de Maisières-Canal (Belgique). p 27-8. In French.

Hahn J. 1988. 1. Fiche sagaie à base simple de tradition aurignacienne. In: Delporte H, Hahn J, Mons L, Pinçon G, de Sonneville-Bordes D, editors. Sagaies. Fiches typologiques de lindustrie osseuse préhistorique, Cahier I. Union Internationale des Sciences préhistoriques et protohistoriques: Commission de Nomenclature sur l'Industrie de les préhistorique. p 117. In French.

Hedges REM, Millard AR. 1995. Bones and groundwater: towards the modelling of diagenetic processes. Journal of Archaeological Science 22:155-64.

Hedges REM, Housley RA, Law IA, Bronk CR. 1989a. Radiocarbon dates from the Oxford AMS system: Archaeometry datelist 9. Archaeometry 31(2):207-34.

Hedges REM, Law IA, Bronk CR, Housley RA. 1989b. The Oxford accelerator mass spectrometry facility: technical developments in routine dating. Archaeometry 31:99-113.

Hedges REM, Housley RA, Bronk Ramsey C, van Klinken GJ. 1994. Radiocarbon dates from the Oxford AMS system: Archaeometry datelist 18. Archaeometry 36(2):337-74.

Hedges REM, Lee-Thorp JA, Tuross NC. 1995. Is tooth enamel carbonate a suitable material for radiocarbon dating? Radiocarbon 37(2):285-90.

Holmes KM, Robson Brown KA, Oates WP, Collins MJ. 2005. Assessing the distribution of Asian Palaeolithic sites: a predictive model of collagen degradation. Journal of Archaeological Science 33:971-86.

Jacobi RM, Pettitt PB. 2000. An Aurignacian point from Uphill Quarry (Somerset) and the earliest settlement of Britain by Homo sapiens sapiens. Antiquity 74(285):513-8

Jacobi RM, Rowe PJ, Gilmour MA, Grün R, Atkinson TC. 1998. Radiometric dating of the Middle Palaeolithic tool industry and associated fauna of Pin Hole Cave, Creswell Crags, England. Journal of Quaternary Science 13(1):29-42.

Jacobi RM, Higham TFG, Bronk Ramsey C. Forthcoming. Radiocarbon dating of Middle and Upper Palaeolithic bone in the British Isles: improved reliability 
using ultrafiltration. Journal of Quaternary Science.

Jöris O, Álvarez Fernández E, Weninger B. 2003. Radiocarbon evidence of the Middle to Upper Palaeolithic transition in southwestern Europe. Trabajos de Prehistoria 60(2):15-38.

Kozlowski JK, Otte M. 2000. The formation of the Aurignacian in Europe. Journal of Anthropological Research 56(4):513-34.

Law IA, Hedges REM. 1989. A semi-automated bone pretreatment system and the pretreatment of older and contaminated samples. Radiocarbon 31(3):247-53.

Leroy-Prost C. 1979. Lindustrie osseuse aurignacienne essai régional de classification: Poitou, Charentes, Périgord (suite). Gallia Préhistoire 22(1):205-370. In French.

Longin R. 1971. New method of collagen extraction for radiocarbon dating. Nature 230:241-2.

Maddy D, Lewis SG, Scaife RG, Bowen DQ, Coope GR, Green CP, Hardaker T, Keen DH, Rees-Jones J, Parfitt S, Scott K. 1998. The Upper Pleistocene deposits at Cassington, near Oxford, England. Journal of Quaternary Science 13:205-31.

Mellars PA. 2004a. Stage 3 climate and the Upper Palaeolithic revolution in Europe: evolutionary perspectives. In: Cherry J, Scarre C, Shennan S, editors. Explaining Social Change: Studies in Honour of Colin Renfrew. Cambridge: McDonald Institute for Archaeological Research. p 27-43.

Mellars PA. 2004b. Neanderthals and the modern human colonization of Europe. Nature 432:461-5.

Mellars PA, Bricker HM. 1986. Radiocarbon accelerator dating in the earlier Upper Palaeolithic. In: Gowlett JAJ, Hedges REM, editors. Archaeological Results from Accelerator Dating. Oxford: Oxford University Committee for Archaeology, Monograph 11. Institute of Archaeology, University of Oxford. p 73-80.

Movius HL, editor. 1975. Excavation of the Abri Pataud, Les Eyzies (Dordogne). American School of Prehistoric Research 30. Cambridge, USA: Peabody Museum, Harvard University.

Movius HL, editor. 1977. Excavation of the Abri Pataud, Les Eyzies (Dordogne): stratigraphy. American School of Prehistoric Research 31. Cambridge, USA: Peabody Museum, Harvard University.

Nelson DE. 1991. A new method for carbon isotopic analysis of protein. Science 251:552-4.
Oakley KP, Campbell BG, Molleson TI. 1971. Catalogue of Fossil Hominids, Part II: Europe. London: British Museum (Natural History).

Sinitsyn AA. 2003. A Palaeolithic 'Pompeii' at Kostenki, Russia. Antiquity 77(295):9-14.

Stuiver M, Polach HA. 1977. Discussion: reporting of ${ }^{14} \mathrm{C}$ data. Radiocarbon 19(3):355-63.

Stafford TW, Jull AJT, Brendel K, Duhamel RC, Donahue DJ. 1987. Study of bone radiocarbon dating accuracy at the University of Arizona NSF accelerator facility for radioisotope analysis. Radiocarbon 29(1): 24-44.

Stafford TW, Hare PE, Currie L, Jull AJT, Donahue DJ. 1991. Accelerator radiocarbon dating at the molecular level. Journal of Archaeological Science 18:35-72.

Tisnerat-Laborde N, Valladas H, Kaltnecker E, Arnold M. 2003. AMS radiocarbon dating of bones at LSCE. Radiocarbon 45(3):409-19.

van Klinken GJ. 1999. Bone collagen quality indicators for palaeodietary and radiocarbon measurements. Journal of Archaeological Science 26:687-95.

van Klinken GJ, Hedges REM. 1995. Experiments on collagen-humic interactions: speed of humic uptake, and effects of diverse chemical treatments. Journal of Archaeological Science 22:263-70.

van Klinken GJ, Mook WG. 1990. Preparative high-performance liquid chromatographic separation of individual amino acids derived from fossil bone. Radiocarbon 32(2):155-64.

van Klinken GJ, Bowles AD, Hedges REM. 1994. Radiocarbon dating of peptides isolated from contaminated fossil bone collagen by collagenase digestion by reversed-phase chromatography. Geochimica et Cosmochimica Acta 58(11):2543-51.

Von Endt DW, Ortner DJ. 1984. Experimental effects of bone size and temperature on bone diagenesis. Journal of Archaeological Science 11:247-53.

Vrielynk O. 1999. La chronologie de la préhistoire en Belgique. Inventaire des datations absolues. Liège: Mémoire de la Société Wallonne de Palethnologie 8. In French.

Wild EM, Teschler-Nicola M, Kutschera W, Steier P, Trinkaus E, Wanek W. 2005. Direct dating of early Upper Palaeolithic human remains from Mladeč. Nature 435(7040):332-5. 